\title{
PORTUGUESE KNIGHTS-ERRANT IN NINETEENTH- CENTURY PARIS AND RIO: TRANSLATION AS RESPONSE TO EXILE IN GLOBAL CITIES
}

\author{
Rita Bueno Maia* \\ Universidade Católica Portuguesa
}

\begin{abstract}
This article aims to uncover the role played by a series of picaresque novels translated into Portuguese and published in midnineteenth-century Paris in helping the Portuguese diaspora cope with the challenges of being a migrant in a global city. Through a contextual analysis, it will be argued that these novels were part of vaster cultural projects aimed at establishing solidarity networks among Portuguese exiles in Paris and, at the same time, at preserving multilingualism. By means of a textual analysis of Dom Severino Magriço ou o Dom Quichote portuguez (Paris, Pillet Fils Aîné, 1851), it will be suggested that this particular target text is committed to helping Portuguese migrants in Paris and in Rio de Janeiro. Furthermore, this novel illustrates ways of engaging with multiple Others, mainly through the reading and comparing of national literary canons.
\end{abstract}

Keywords: (Absolutist) Exile. Cosmopolitan. Solidarity. Herderian Revolution. Don Quijote.

* Rita Bueno Maia: holds a PhD in Translation History from the University of Lisbon (2012). She is assistant professoir of Hispanic and Translation Studies at the School of Human Sciences of the Catholic University of Portugal. Lisbon, Portugal. E-mail: rbuenomaia@fch.lisboa.ucp.pt. 


\title{
CAVALEIROS ANDANTES PORTUGUESES EM PARIS E NO RIO DURANTE O SÉCULO XIX: TRADUÇÃO COMO RESPOSTA AO EXÍLIO EM CIDADES GLOBAIS
}

\begin{abstract}
Resumo: $\mathrm{O}$ presente artigo procura explorar a forma como um corpus de romances picarescos traduzidos para português e publicados em Paris em meados do século XIX poderá ter intentado ajudar a diáspora portuguesa a lidar com o desafio de ser migrante numa cidade global. Através da análise contextual, argumentar-se-á que estes romances formaram parte de projetos culturais mais latos com o objetivo de estabelecer redes de solidariedade entre os exilados portugueses em Paris e, ao mesmo tempo, de conservar o multilinguismo na comunidade migrante. Através da análise textual da obra Dom Severino Magriço ou o Dom Quichote Portuguez (Paris, Pillet Fils Aîné, 1851), defender-se-á, primeiramente, que este texto parece mostrar um compromisso em falar para os exilados absolutistas portugueses em Paris e, provavelmente, no Rio de Janeiro. Depois, tentar-se-á demonstrar que a diegese deste romance apresenta formas de dialogar com múltiplos Outros. Concretamente, este texto de chegada, inspirado na obra de Cervantes e formado por fragmentos traduzidos de diferentes textos de partida, parece aconselhar o leitor a, por um lado, não ter medo do desconhecido e, por outro, conhecer os vizinhos globais através da leitura e comparação de cânones literários nacionais.
\end{abstract}

Palavras-chave: Exílio absolutista. Cosmopolita. Solidariedade. Revolução Herderiana. Dom Quixote.

\section{Introduction}

In the 2015 call of Humanities in the European Research Area (HERA) for joint research projects, entitled "Past Mobilities and Mobile Pasts", one of the stated aims was: “[To] [s]tudy and understand how past mobilities inform contemporary ones, through a combination of historical (archival) and anthropological (ethnographic) methods." This agenda as set out by HERA seems to be motivated by contemporary concerns on the part of European countries as they play host to migrants of multiple origins in a time when European citizens are still negotiating a new imposed transnational identity. 
As regards the historical (archival) method, a first step towards a more comprehensive understanding of the experiences, needs and responses of mobile communities would be the study of past communities. In order to inform contemporary migratory movements, the archive researcher, besides analysing the historical specificities of each case study, should look for patterns in different mobile experiences, especially as regards challenges and responses.

The present article aims at presenting the results of the research project The Moveable Feast (1838-1853): Literature in Portuguese Exile (SFRH/BPD/97092/2013), which explores popular literature published in Paris in Portuguese between 1834 and 1853. This case study focuses on a relevant historical episode of mobile communities using a literary activity, namely translation, to cope with the challenges of the migrant experience in global cities.

The first section of the article provides a brief discussion of the concepts of inter-historicity (Guillén 1995), global city (van der Veer 2002 and Cronin 2006), cosmopolitan reading (Domínguez 2010) and cosmopolitan options (van der Veer 2002). These concepts constitute the theoretical framework that allows for the proposal of an explanatory hypothesis for the literary phenomenon under study.

Taking into consideration the fact that this literary corpus, which encompasses at least twelve anonymous novels, has never so far been studied, in the second section of the article some of the results of the archaeological phase of the project will be presented. That is to say, data will be provided so that the research questions, as asked by Anthony Pym, of "who translated what, how, where, when, for whom and with what effect?" (Pym 1998, 5) can be addressed.

Finally, the textual analysis of a particular target text, Dom Severino Magriço ou o Dom Quichote Portuguez [Dom Severino Magriço or the Portuguese Don Quijote] (Paris 1851), will be undertaken. The aim of this analysis is to demonstrate the presence of textual elements that can be classified as inter-historical, i.e., as constitutive of literary responses to the challenges of the migrant 
in different historical contexts, and to study the shaping of these textual elements in this particular target text.

\section{Recurrent responses to a common experiential field}

In the study of the current challenges linked to issues of mobilities, Peter van der Veer and Michel Cronin argue for global cities to be understood as privileged sites for inquiring into the tensions faced by today's migrants as well as into migrant responses to these challenges. These global cities are urban centres that display the imprint of multiple migrant communities from different backgrounds as a "product of the increased mobility of capital and labour" (van der Veer 2002, 24).

According to van der Veer, current transnational cosmopolitan projects defy the traditional notion of cosmopolitanism, which is, as the author argues, a colonial trope of Western Enlightenment. ${ }^{1}$ In twenty-first century global cities it is possible to find institutions that are primarily reserved for migrants' projects aimed at promoting dialogue between communities. Contrary to the nineteenth-century notion of cosmopolitanism, which opposed "non-interference" - as the attitude of the provincial - to "cultural engagement" - as the attitude of the cosmopolitan - (24), these new cosmopolitan options provide the migrant both with a place of reunion with the Self and with projects of cultural engagement with the Other.

Michael Cronin is the scholar whose works are probably most in line with the objectives announced by HERA in the "Past

\footnotetext{
"If we are looking for a postcolonial cosmopolitanism it is the global city that must be examined. (...) Transnational movements that help migrants to cope with the conditions of migration and labour flexibility, such as Tablighi Jama'at in Islam, do not simply build religious enclaves, safe havens of the self, but creatively develop new religious understandings of their predicament, entailing an encounter with the multiplicity of Others on their own terms. It is impossible to simply call these movements closed, confined and confining, that is they engage the Other, but they emerge from quite different histories than those of the European Enlightenment" (van der Veer, 2002, 25).
} 
Mobilities and Mobile Pasts" project. The analysis of multiple case studies on how different migrant communities have dealt with each other in different global cities throughout history is, for Cronin, the first step towards a new cosmopolitan project. In his 2006 and 2012 works, Cronin argues for a new cosmopolitanism, one that is founded on the politics of microspection. That is to say that this new cosmopolitanism demands a new theoretical standpoint, both epistemological and political, that would allow it to focus on the complexity of the local in terms such as hybridity and migration, rather than on the macro-globalised world (Cronin 2012, 12).

In the micro-cosmopolitan approach, translation emerges as a central object of analysis for two main reasons, the first being the role played by translation activities in the establishment of local solidarity networks. Similar to van der Veer's cosmopolitan options, these solidarity networks, which are (or should be) founded on the basis of cosmopolitan projects, are constructed through local activities that join, on the one hand, interaction - developing new cultural understandings of the Self and the Others:

[I]f translation is primarily a form of interaction with another language and culture (which in turn modify one's own), then it is surely to translation we must look if we want to think about how global neighbourhoods are to become something other than the site of non-interactive indifference. (Cronin 2006, 68)

- and, on the other, acts of resistance against linguistic assimilation:

Is all the translation to be unidirectional, and assimilationist or is there a moment when the refusal to be translated into the dominant language or the demand for translation into the immigrant's language becomes a conscious form of resistance, a desire to assert language rights, namely those relating to the maintenance of the mother tongue? (56) 
The second reason for bringing translation to the forefront of new cosmopolitan projects is the ability of a transnational archaeology of literature in Europe to highlight the cosmopolitan connectedness of national literary canons and languages. This in turn, Cronin argues, will assist the European Union in the long run with reconfiguring its supranational cultural identity.

Focusing on the same challenges of today's mobilities specifically on the condition of the exile and on EU transnational cultural identity - the works by Cláudio Guillén and César Domínguez analyse a set of strategies displayed in original Spanish novels as recurrent literary responses to these challenges.

In his 1995 book, El sol de los desterrados, Guillén brings forward an inter-historical hypothesis, that is to say, a hypothesis derived from the dialogue between historicity and recurrence, regarding the relation between literature and a particular case of mobility: the exile experience. Guillén's definition of interhistoricity reads as follows:

Interhistoricity examines first of all the different responses found in more than one period to a common experiential field and then constructs - not as a premise but as a precipitate of our knowledge of the periods involved - sets of options covering, if possible, the width and breadth of the field. (1990, 261; see also Guillén 1995, 14)

Guillén analyses a series of literary works shaped by the exile experience or written as a response to this "common experiential field". According to the author, there is a phenomenon prior to the quantitative expansion of Iberian exiles in the mid-nineteenth century that is worth mentioning: that of the Spanish picaresque novel. For instance, in the novels of Antonio Enríquez Gómez (1600-1663), the topos of the journey of the marginalised is interrelated to the author's exile, an exile provoked by accusations of Judaism. As response to the persecution of the conversos, the 
picaresque genre has symbolically conveyed, in Guillén's words, "formas de vida viajera, cambiante, migratoria, como la del pícaro y la del peregrino" (Guillén 1995,103).

Moving on to the late twentieth and twenty-first centuries, César Domínguez analyses the power of contemporary novels in helping readers to cope with the challenges of Europeanisation. The four novels Domínguez analyses ${ }^{2}$ have in common: (i) a Robinsonade structure; (ii) a series of comparisons in the diegetic level between characters of different nationalities who cohabit the same global cities, (iii) and, last but not least, explicit mentions of the process of Europeanisation. In parallel to the comparisons set in motion by these contemporary novels, EU citizens negotiate their regional, national and transnational identities by questioning the role and the relevance of age-old so-called European literary masterpieces.

According to Domínguez, the power of contemporary novels to help readers to deal with the distressful transition between a national past and a transnational shared future depends on a particular reading pact, which Domínguez calls cosmopolitan reading (2010, 192-194). That is, in order for readers to read in this particular way, they would have to share the same experience of implosion of borders, multiple mobilities and global cities. As textual evidence of the reciprocal working of this pact, Domínguez alludes to the explicit references to Europeanisation in the novels.

In this context, the following section presents the outcomes of the research conducted on the contextual history of the Portuguese target texts published in mid-nineteenth-century Paris. It will be argued that both the producers and the readers of this popular novels shared a similar mobile experience and, further, that the institutional sites of production and reading of these novels were spaces of solidarity - cultural interaction and linguistic resistance - between Portuguese migrants. Subsequently, a particular target text, Don Severino Magriço or the Portuguese Don Quijote, will

${ }^{2}$ El año de Gracia (1985) by Cristina Fernández Cubas, Europa (1997) by Tim Parks, Ciudadanos de la Tierra.com (2004) by Joaquín Lorente, and La fi d'Europa (2006) by Àngel Burgas. 
be analysed in order to look for explicit references to the political conditions of this particular episode of exile. Finally, a hypothesis will be presented on how this particular target text type correlates with the potential of a literary work to speak directly to Portuguese migrants in two nineteenth-century global cities.

\section{Common experiential field: who translated what, when, where, for whom?}

\subsection{Who translated what and when?}

In order to understand the political context in which the popular literature under study was published, as well as the political engagement of its producers, some background knowledge concerning the military events in Portugal during the first half of the nineteenth century is required.

After the Napoleonic Wars (1807-1810), which led to the Portuguese Royal Family fleeing to Brazil, Brazil's independence was proclaimed in 1822 . To the dismay of the majority of the Portuguese people, the prince heir Dom Pedro remained in the former colony while his brother, Dom Miguel, usurped the Portuguese throne, establishing an Absolutist regime. In 1834, after six years of civil war (1828-1834), Dom Pedro restored the Constitutional Monarchy in Portugal. This, in turn, led to the exile of Dom Miguel (first to Genoa and then Rome) and his supporters in 1834.

Between 1838 and 1853 a series of twelve popular novels was published in Portuguese in Paris. These popular novels have the following three common features: ${ }^{3}$ firstly, regarding their generic characterisation and following the preliminary readings of Ramos $(1972,31)$ and Oliveira $(2013,42)$, they are picaresque narratives in which adventures are structured around a journey with no particular

${ }^{3}$ Except if otherwise noted, the data provided concerning the identification of the source texts proceed from the results of the ongoing postdoctoral project mentioned earlier.

Cad. Trad., Florianópolis, v. 37, no 1, p. 159-187, jan-abril 2017 
destination, thus enabling multiple encounters at the diegetic level; secondly, they were published anonymously, as exemplified by the 1849 Portuguese translation of Francisco de Quevedo's El buscón, bearing neither the author's name nor that of the translator (see Maia 2012, 146); thirdly, they are textually hybrids in that they mix translated fragments from different source texts and original writing. For example, the 1840 novel Dom João da Falperra ou aventuras d'esse celebre personagem [Dom João da Falperra or the Adventures of that Famous Character] is based on the 1736 French novel La Mouche et les espiègleries et aventures galantes de Bigand, by Charles de Fieux, Chevalier de Mouhy. Nevertheless, many of the chapters in the Portuguese target text are not taken from this source text; they originate either from other source texts or from the Portuguese translator's creative imagination.

Regarding the translators responsible for these target texts, it is not possible at this stage to do more than hypothesise. Even if not amounting to conclusive evidence, a common feature of these novels' plots seems to suggest that these translators were, in fact, Portuguese (and not Brazilian). In these novels the protagonists are always described as being of Portuguese origin. In other words, it seems that the translators selected source texts with Portuguese protagonists. The 1838 novel D. Raimundo d'Aguiar ou os frades portuguezes [Don Raimundo d'Aguiar or the Portuguese Friars] is based on the 1788 novel Raphael d'Aguilar ou les Moines Portugais, by Charles Gabriel Porée and rewritten by Bassilon de Rougemont. The opening line of this French novel reads: "Don Fernand d'Aguilar, après avoir fait une fortune considerable au Brésil, revint à Lisbonne, sa patrie..." The 1853 text Viajens $e$ aventuras d'hum jovem portuguez. [Voyages and Adventures of a Young Portuguese] is a translation of the 1797-1798 novel Alphonse et Dalinde by the Comtesse de Genlis. The opening line of this French novel reads: "Alphonse, le héros de cette histoire, naquit en Portugal."

The archival research conducted so far on literary agents and their professional networks working in the Portuguese language 
in Paris in the mid-nineteenth century indicates the existence of two separate groups. On the one hand, the hired translators, on the other, the independent translators. However, in order to fully understand these two categories further historical information is needed about the market for translated books in Paris.

In nineteenth-century Paris it was mandatory that book agents possess a brevet, i.e., a written authorisation to practice one of the following professions: either bookseller or publisher (Laharie 2003). Therefore, some booksellers would hire typographers and would commission literary translations to sell in their bookshops. This seems to have been the case of Jean-Pierre Aillaud (17851852), a bookseller who sold several Portuguese translations in mid-nineteenth-century Paris. In the multiple literary translations published by Aillaud, the front page bore the name, address and logo of this French-Portuguese bookseller and, on the last page, the name and address of the printing house.

Aillaud hired high-rank Portuguese exiles as in-house translators. Among these exiles were António José Viale (1806-1886), who had worked in the Ministry of War until 1833 and, after a decade of exile in Paris was to become the tutor of the future kings D. Pedro V and D. Luís I (Maia 2012, 172-173), and João da Cunha Neves e Carvalho Portugal, who had been Chief Judge in Oporto under the Absolutist Regime and had the thankless task of judging partisans of the Constitutional Monarchy accused of rebellion in $1828 .{ }^{4}$ These two figures will be referred to again in the following section. Another translator worth mentioning is Caetano Lopes de Moura (1780-1860), a Brazilian who was in Portugal during the Civil War and, due to his Absolutist entourage, had to flee to Paris in 1834 (see Veiga 1972).

Despite the fact that these Portuguese exiles were respectable intellectuals, evidence suggests that the bookseller was actually the

\footnotetext{
${ }^{4}$ All information concerning João da Cunha Neves e Carvalho Portugal's occupation during the Absolutist years (1828-1834) is (surprisingly) missing from Viale 1861. Nevertheless, the work by Soriano $(1866-1890,197)$ reproduces the letter in which King Dom Miguel appoints Carvalho Portugal as Surrogate Chief Judge in the case against the Liberal rebels, following an insurrection in Oporto on May 16, 1828.
} 
initiator of the majority of the translation processes. For instance, in the inscription of the Portuguese translation of a French book by Tarbée des Sablons, Aillaud addresses the following words to Queen Maria II: “confiei a tradução do presente livro ao Doutor Caetano Lopes de Moura (bem conhecido pelas suas estimáveis traduções) (...)" [I commissioned the translation of the present book to Caetano Lopes de Moura (well-known for his respectable translations)]" (quoted in Veiga 1972, 115).

The case of Portuguese translators responsible for the publication of picaresque adventurous literature in covert translations of French novels seems to have been slightly different. In contrast to the translations commissioned by the bookseller Jean-Pierre Aillaud, the peritext of these popular novels displays only the name of their publishers, namely Imprimerie Beaulé et Jubin, Pommeret et Guénot imprimeurs. This seems to suggest that the Portuguese translators themselves selected the source texts and submitted the manuscript to print, probably at their own expense. The published book would be afterwards sold in a bookshop.

\subsection{Where?}

According to the results of my research of the Q10 collection, i.e., the collection of catalogues of booksellers and publishers available at the Bibliothèque Nationale de France, these target texts, even though not commissioned by Aillaud, could be purchased at Aillauds's Portuguese Bookshop in Paris. Aillaud's 1844 catalogue consists of two different sections: one advertising "books published by J.P. Aillaud" and a second one displaying the title "other Portuguese books published in Paris" (13), where entries for the above-mentioned novels can be found.

Evidence suggests that Aillaud was also in charge of the distribution of these popular novels in Paris and abroad. Firstly, Aillaud's 1851 catalogue, written entirely in Portuguese, has two different versions: one intended for readers and another, displaying the same titles but with slightly lower book prices, intended for 
booksellers. Secondly, since none of the titles mentioned in section 3.1. was found in any of the other French booksellers' catalogues, it is plausible that Aillaud exported these novels. For this reason, research was conducted at the Historical Archive of the Portuguese National Library in Lisbon and at the Digital Library of the Brazilian National Library.

During the 1840s all books imported by Lisbon booksellers had to be presented to the Chief Librarians of the Portuguese Royal Library in order to be taxed according to specific criteria (Garcia and Martins 1996, 111). Having analysed the Reports of Imported Books from 1843 to 1847 held at the Historical Archive of the Portuguese National Library, it is possible to state that, while there was an abundant importation of Aillaud's editions, none of the popular novels of the present corpus was imported. Additionally, in a previous work (Maia 2012, 164), evidence has been given that these anonymous target texts were not listed in the catalogues of the Portuguese booksellers operating in Lisbon.

Based on the data collected so far, it is possible to argue that these anonymous novels were also meant for the Brazilian market, most notably for Rio de Janeiro. However, it should be noted that the export of these novels appeared to have been somewhat irregular. This would suggest that their primary market was Paris.

Focusing exclusively, for the sake of clarity, on the titles mentioned in section 3.1, the collected data shows that in 1849 the Portuguese émigré Agostinho de Freitas Guimarães (23) was advertising the novels Dom Raimundo d'Aguiar (1838) and Dom João da Falperra (1840), both of which could be purchased in his bookshop. The 1858 catalogue of the Portuguese Reading Cabinet, which served also as a lending library, contains both these two titles and also Viajens e aventuras d'hum jovem portuguez (1853). Finally, the 1866 catalogue of Biblioteca Fluminense (168), another reading room and lending library, again includes the first two titles (1838 and 1840) and the 1849 covert Portuguese translation of El buscón. 


\subsection{For whom?}

It is possible to pinpoint two types of readers in mid-nineteenthcentury Paris: Portuguese exiles and Portuguese and Brazilian students. In his posthumous novel $A$ cidade e as serras (1901) [The City and the Mountains], the Portuguese writer Eça de Queirós (1845-1900) tells the story of the descendant of a Portuguese nobleman, Jacinto Galião, whose ridiculous devotion to king Dom Miguel, a devotion arising from the fact that the king had helped Jacinto to recover from a fall, spurred him to move to Paris:

For he had no wish to remain in that perverse land which the plundered and banished King of Portugal - that picker-up of Jacintos - was now leaving. He embarked for France with his wife, Senhora Dona Angelina Fafes (...), his son Jacintinho (...), the nursemaid, and a black servant-boy. (Eça 2008, 3)

The fictional story of Jacinto Galião mirrors real life Portuguese exiles such as Visconde de Santarém (1791-1856) or Duque do Cadaval (see Protásio 2016, 125-127 and 163-177), who, rather than following the king to Rome, chose a peaceful life with their families and servants in Paris, away from political turmoil.

Between 1838 and 1843, a Portuguese school with Portuguese teaching staff and Portuguese-speaking students operated at Fontenay-aux-Roses near Paris. Several Portuguese exiled noblemen worked as teachers in this establishment, as did former soldiers from Dom Miguel's troops. ${ }^{5}$ As for the composition of the student body, according to Boaventura (2012), there were 73 pupils in the institution, mainly Portuguese and Brazilian with a minority of 14 or 15 French students.

\footnotetext{
${ }^{5}$ In fact, in one of the very few existing first-person testimonies of the Civil War by a supporter of Dom Miguel is written by a former soldier. António Guedes Quinhones (1990, 39) wrote that many of his colleagues had to flee the country for Rome, London and Paris to escape two threats: popular persecution and famine.
} 
With the profile of the Lusophone mobile community thus established, one might wonder about the number of the Portuguese exiles in Paris. According to the Institut National de la Statistique et des Etudes Economiques (INSEE), in 1851 Portuguese was not among the top seven nationalities living in Paris; Portuguese residents were thus included under the category "Foreigners, other foreigners" (see Table 1).

Table 1. Exiles in Paris in 1851 (INSEE)

\begin{tabular}{|l|l|}
\hline Nationality & Nr. of Habitants Seine Department 1851 \\
\hline Allemands & 13584 \\
\hline Belges & 12156 \\
\hline Italiens & 9562 \\
\hline Suisses & 6030 \\
\hline Anglais & 5781 \\
\hline Polonais & 2600 \\
\hline Espagnols & 1321 \\
\hline $\begin{array}{l}\text { Etrangers, autres } \\
\text { etrangers }\end{array}$ & $\mathbf{1 1 2 0 7}$ \\
\hline
\end{tabular}

It was not until the 1876 census that the number of Portuguese residing in Paris - 665 - was made available and whereas the number of Brazilians in the city, included in the "Americans from the North and the South" category, was still unavailable (see Table 2).

Table 2. Exiles in Paris in 1876 (INSEE)

\begin{tabular}{|l|l|}
\hline Nationality & Nr. of Habitants Seine Department 1876 \\
\hline Anglais, écossais, irlandais & 10509 \\
\hline Américains du nord et du sud & $\mathbf{6 2 2 6}$ \\
\hline Allemands & 21834 \\
\hline Autrichiens et hongrois & 3667 \\
\hline Belges & 40816 \\
\hline
\end{tabular}




\begin{tabular}{|l|l|}
\hline Hollandais & 9438 \\
\hline Italiens & 12838 \\
\hline Espagnols & 3467 \\
\hline Portugais & 665 \\
\hline Russes et polonaise & 4796 \\
\hline Suédois, norvégiens, danois & 825 \\
\hline Grecs & 330 \\
\hline Turcs, égyptiens etc. & 714 \\
\hline Roumains, serbes etc & 584 \\
\hline $\begin{array}{l}\text { Chinois, indiens et autres } \\
\text { asiatiques }\end{array}$ & 205 \\
\hline Autres étrangers & 1817 \\
\hline
\end{tabular}

Given that members of the Portuguese-speaking community were a minority in a city with a growing number of diverse mobile communities, it is worth to remark that a Portuguese bookshop was operating in Paris between 1820 and 1870. While this bookseller was engaged in commissioning and selling mainly literary translations, thus promoting literary exchange, JeanPierre Aillaud's establishment, both as a shop and place of work, seems to have functioned also as a Portuguese cultural centre, a meeting space and sometimes even a private refuge for Portuguese migrants. In other words, following Cronin and van deer Veer, Aillaud's bookshop in Paris appears to have provided a place of non-interference for the Portuguese-speaking community, thus stimulating the establishment of local solidarity networks among exiles; it seems, at the same time, to have supported cultural engagement, namely by sponsoring Portuguese translations of foreign literary works.

In an entry to his journal dated 8 June 1843 , Ferdinand Denis, the director of the Bibliothèque Sainte Geneviève who had grown up in Brazil, wrote: "Le hasard m'ayant conduit chez l'éditeur Aillaud, à propos du mot fato, mal interprété dans toutes les traductions de Camoens (...) j'ai fait la connaissance de M. Roquete, l'éditeur 
du Leal Conselheiro. Il tenait à la main le Cancioneiro de D. Diniz..." (Denis 1932, 126). Thus, in order to clarify a word in a Portuguese epic poem, Denis visits Aillaud's house and bookshop where Portuguese exiles worked and met to discuss Portuguese literature and where Portuguese historical literary sources were to be found. This seems to indicate that Aillaud's bookshop provided a social space for its employees and customers similar to that made available by the Portuguese Reading Cabinet in Rio de Janeiro to its shareholders and subscribers.

In his research project on the profile of the Portuguese Reading Cabinet's users, Fabiano Cataldo Azevedo (2008) draws the following conclusions. Firstly that the Cabinet, created by Portuguese émigrés who had fled the Civil War, had two main purposes: to provide a meeting space for the migrant community and to function as a Portuguese cultural embassy. Secondly, the Portuguese Reading Cabinet had as its users Portuguese immigrants and, to a lesser extent, high-ranking Brazilian citizens. Therefore, Azevedo (2008) concludes that the success of this establishment can be explained by the different migratory movements of Portuguese citizens, especially those from the North of Portugal, to the capital of the Empire. In this migratory movement, which began with the Civil War and lasted until the second half of the nineteenth century, a high number of Portuguese doctors, lawyers and merchants moved to Rio de Janeiro in search of better professional opportunities.

Furthermore, Abreu et al. (2015) inform us that the Portuguese Reading Cabinet was one of several "associative institutions" in nineteenth-century Rio de Janeiro that shared the aim of bringing together particular migrant communities. In response to the growing number of immigrants, there arose associations providing migrant communities with a place to meet and with publications (books, periodicals, etc.) in their own language. Examples of these enclaves include the Germanic Society (founded in 1821), the British Subscription Library (established in 1826) and the Cercle Suisse (founded in 1873). 


\section{Don Severino Magriço or the Portuguese Quijote}

\subsection{Covert references to King Dom Miguel}

In order to argue that the particular target text Dom Severino Magriço ou o Dom Quichote Portuguez might have been published as a response to the exile and migrant experience of the Portuguese population in Paris, it would be reassuring to find explicit mention of this common experience in the text, i.e., references to the historical motives that led to the decision to embark on a lifelong exile. This novel is presented as an original text and indeed some of the chapters seem to have been originally written in Portuguese. However, it was possible to identify the translation of various fragments from multiple source texts.

Before arguing that such references can indeed be found in the text, it is necessary to draw attention to the situation of censorship and freedom of speech in nineteenth-century Portugal. Despite the fact that institutional censorship was abolished in 1834, evidence suggests that references to the Absolutist government were not tolerated in the public sphere even after that date.

In 1861, 27 years after the end of the Civil War and 10 years after the publication of our target text, António José Viale, royal councillor and former partisan of the Absolutist party, delivered the funeral oration of another former Absolutist - João da Cunha Neves e Carvalho Portugal - during a session of the Lisbon Academy of Sciences. In his narration of the public career of the deceased, no explicit mention was made of the Civil War or of the Absolutist government, although Viale $(1861,7)$ states that he did not wish to omit anything, because "um silêncio absoluto sobre a continuação da carreira publica do Sr. João da Cunha [entre 1828 e 1834] poderia ser da minha parte um effeito de cobardia" [an absolute silence about João da Cunha's later public career [between 1828 and 1834] would sound cowardly on my part]. It seems plausible to assume that the use of italics in the printed version signals a change of tone or emphasis in the speaker's oral delivery, thus 
drawing to a shared political (Absolutist) past with the deceased. This (highly) veiled reference was undoubtedly understood as such by the audience who heard the speech in 1861 .

Accordingly, the reader of novels such as Don Severino Magriço hoping to find any reference to King Dom Miguel should bear in mind that only concealed allusions were acceptable in midnineteenth century. In fact, all partisans of the Absolutist regime who had not been granted Royal pardon were denied the right to speak publicly, at least as far as Portuguese political matters were concerned. ${ }^{6}$ This is likewise the most probable reason that accounts for the decision to publish these works anonymously.

At the end of the first volume of the novel, Don Severino Magriço dines with an anonymous character who tells the story of Lord King Roderic, the last king of the Goths (1851, 155-160). The similarities between this story and the history of Dom Miguel would have been easily recognised by the Portuguese reader. King Roderic ignores all prophetic warnings and enters an enchanted tower in order to obtain treasures that would allow him to fund the war. As a result of the king's stubborn boldness, the most terrible of curses as uttered by an enchanted statue is fulfilled: "Unfortunate prince, you will be dethroned by foreign nations" (159).

In a similar situation to that of the legendary Roderic, in order to fund the war King Dom Miguel, against all prudent advice, contracted a heavy loan from the French state. Furthermore, his brother, King Dom Pedro, was able to establish a so-called Quadruple Alliance between Portugal, Spain, England and France and, ultimately, dethrone Dom Miguel.

Besides these similarities, a closer look into this episode seems to confirm that the story of King Roderic is indeed a covert reference

\footnotetext{
${ }^{6}$ The Article 2 of the 1834 peace treaty ("Convenção de Évora-Monte") reads as follows: "Quaisquer amnistiados nacionais ou estrangeiros poderão livremente sair de Portugal, e dispor de seus bens, com tanto que (...) que dêem a sua palavra de não tomarem parte de qualquer modo nos objectos políticos destes reinos" (Ventura, 2008, 124) ("All persons amnestied, Portuguese or foreign, may freely leave Portugal and dispose of their belongings provided that (...) they give their word to not take part in any way in the political affairs of the kingdom" [Thomson 2014, 94]).
} 
to the last king of the Ancien Régime. The findings of my research suggest that this fragment of text is in fact the translation of the entry "Rodrigue, Roderik" from the Encyclopédie théologique et dictionnaire des sciences occultes. A comparison between the two first sentences shows that while the Portuguese translator introduces King Roderic as the "usurper Roderic" - "No começo do oitavo século, o usurpador Rodrigo último rei dos Godos..." $(1851,156)$ - the descriptor 'usurper' is missing from the source text, which reads "Roderik, dernier roi des Goths en Espagne..." (Plancy and Simon 1846-1848, 401).

The word "usurper" would be undoubtedly understood by any reader of the time as an allusion to King Dom Miguel ${ }^{7}$. In fact, the Portuguese National Library's catalogue lists five works published in the final year of the Civil War which contain the Portuguese adjective "usurpador" in the title, in all five cases this being a reference to King Dom Miguel. ${ }^{8}$

\footnotetext{
${ }^{7}$ The fact that this anonymous translator chooses to use a derogatory term - usurper - to allude to King Dom Miguel should come as no surprise. Maria Teresa Mónica (Quinhones 1990) has already pointed out that former Absolutists soon became very critical of King Dom Miguel. Most notably, they accused the exiled king of letting his supporters fall into oblivion. It is thus common to read pejorative remarks about King Dom Miguel in texts authored by former Absolutists. In the already quoted funeral oration, António José Viale does not mention a word about Carvalho Portugal's experience as Surrogate Chief Judge in the case against Liberal rebels (1828). However, the author does not omit that Carvalho Portugal had taken part in it as Surrogate Chief Judge against Absolutist rebels four years before. This biographical episode is narrated as follows: "Pouco depois dos acontecimentos políticos de abril de maio de 1824 foi o sr. João da Cunha mandado á província de Trás-os-Montes devassar dos então denominados infantistas e rainhistas (...)" (Viale 1866, 7; emphasis added) [A while after the political events of May and April 1824, João da Cunha was sent to Trás-os-Montes to judge the then called supporters of the Infant and supporters of the Queen (literally: infantists and queenists)]. That is to say that Viale, who had served King Dom Miguel, used derogatory adjectives to refer to the Absolutists. He calls them the supporters of the Infant and the Queen, thus opposing them to the supporters of the (true and only) King.

${ }^{8}$ Ultimo adeos do uzurpador Miguel aos habitantes e tropa de Lisboa. Angra: Imp. da Prefeitura, 1833; A queda de D. Miguel e os males, que o governo usurpador causou à Nação Portugueza. Lisboa: Imp. Nevesiana, 1833; Procedimento que o governo usurpador e o extincto senado praticou com o official maior graduado.... Lisboa: Nova Impr. Silviana, 1833; Epistola ao usurpador ex-infante Miguel Maria do Patrocinio na sua saida de Portugal/António Feliciano de Castilho. Lisboa: Imp. Nacional, 1834. Carta dirigida ao ... senhor Fr. de S. Boaventura ... em que se descrevem alguns factos seus do tempo da usurpa-
} 


\subsection{The literary response to the mobile experience}

Having argued that this particular 1851 Portuguese novel can be read as influenced by the exile experience, it is now necessary to establish whether this literary response can be considered as part of a recurring trend, i.e., in Guillén's terms, an inter-historical topos. In Domínguez's work, the author pinpoints two sets of comparisons that can be made in relation to contemporary novels: one internal and the other external. The first one is the meeting between different characters in the novel, the second one is the questioning, by European citizens, of the European canon. The analysis undertaken on Don Severino Magriço seems to suggest that while these two comparisons can indeed be applied in the case of this novel, they can hardly be considered as separate internalexternal or national clichés-national masterpieces. Rather, they are intertwined in the novel.

The two volumes of Don Severino Magriço narrate the protagonist's journey, a journey with no particular destination, through Portugal and along the African coast. In these wanderings, two types of adventure occur. On the one hand, there are episodes in which the protagonist saves other characters from imaginary threats; the most common example of this type of adventure is one in which a certain "bad fellow" disguised as a werewolf or a ghost is terrorising a village only to be finally unmasked by Don Severino. On the other hand, there are episodes in which the protagonist encounters other mobile characters of different nationalities. In these episodes, the role of Don Severino is as listener while the foreign characters recount their own life stories.

From the second group of episodes, we can highlight the following two examples: the "Story of the Young Salek" (chapters XIX-XXI) and the "Story of a Spanish soldier" (chapter XXIV).

ção e se analysão varios paragrafos das suas obras: principalmente da hypocrisia religiosa de D. Miguel e seus sequazes...e da oração funebre recitada em Queluz nas exequeas da rainha D. Carlota, estando presente o usurpador. Lisboa: Na Imprensa Nevesiana, 1834. 
In the case of these two episodes the aim of the analysis will be limited to identifying the source texts of these chapters, which can be proven to be genuine translated fragments selected from anthologies printed during the period under study here.

Hence, the story of Salek, a young Turk from Constantinople, is in fact the translation of the short story "Le sac d'Abd-êl-Qader ou la destinée" from the 1833 anthology Contes du Cheykh ÊlMohdy (Marcel 1833). The story of the Spanish soldier is the translation of a fragment from Fortuna varia del Soldado Píndaro, by Gonzalo de Céspedes y Meneses, a seventeenth-century Spanish picaresque novel republished in the 1851 anthology Biblioteca de autores españoles: Novelistas Posteriores a Cervantes.

As shown by Pascale Casanova (2004, 78-80), in midnineteenth century the works of Johann Gottfried von Herder provoked a revolution in the "World Republic of Letters". Literary popular traditions were considered as inseparable from vernacular languages and as a product of national spirit that led to an intense production of national literary anthologies. One clear example is the above-mentioned 1851 Spanish collection, the English title of which would be The Library of Spanish Authors.

Having in mind the importance and success of Herder's philosophy, it seems tenable that first-person popular literary narratives - be they an Arabic short story or a picaresque novel - were considered trustworthy sources of national behaviour. Moreover, encounters between people of different nationalities also, and most importantly, provided an opportunity for comparing different literary canons. After all, as mentioned in the title, Don Severino Magriço presents itself as an encounter between the Spanish canonical literary character and the Portuguese national identity: the Portuguese Don Quijote.

Additionally, just as in Cervantes' novel Alfonso Quijano loses his wits by reading chivalric romances, Don Severino decides to embark on his journey while obsessively reading a very different literary corpus: 
O senhor D. Severino erguia-se commummente ás dez horas da manhã, almoçava, e recolhia-se depois ao seu gabinete, onde se enfrascava, té as duas da tarde, nas Décadas de Barros, nas do seu continuador Diogo de Couto, na vida de D. João de Castro, no Segundo Cerco de Diu, nas Peregrinações de Fernão Mendes Pinto (ou Minto), no Palmeirim d'Inglaterra, etc. (1851, 6-7)

From the literary works referred to in the quote it is possible to trace the influence of prose works from the sixteenth-century Portuguese literary canon, cherished as the Golden Age of Portuguese Literature by Romantic authors, e.g. Almeida Garrett (Maia 2012, 266). Furthermore, these prose works have the common trait of bearing testimony to the Age of the Discoveries, i.e. telling the stories of the Portuguese as the great navigators of the past, fearless voyagers to new and unknown lands.

Therefore, while the anonymous author of Don Severino Magriço resorted to foreign anthologies in order to introduce characters from different nationalities, it was the anthology of Portuguese literary works of the Golden Age that provided both the background from which the protagonist emerged and the role models that he followed throughout the novel. In 1837, the Portuguese émigré José da Fonseca published in Paris the anthology Prosas selectas ou a escolha dos melhores logares de autores portuguezes [Selected Proses or the Best Places of Portuguese Authors]. In the table of contents of this Portuguese anthology it is possible to identify the same canon highlighted above: João de Barros (Fonseca 1837, 336), Fernão Mendes Pinto (337), Diogo Couto (338), and Jacinto Freire - the author of $A$ vida de D. João de Castro (339).

\section{Conclusion}

This article has unveiled a literary phenomenon that was involved in the creation and maintenance of solidarity networks 
of Portuguese exiles in Paris and, quite probably, of Portuguese migrants in Rio de Janeiro.

Having started with the contextual analysis of popular literature novels translated into Portuguese between 1838 and 1853, it was possible to argue that the publication of these novels in Paris was part of the literary activities of the Portuguese Bookshop, owned by Jean-Pierre Aillaud. This bookshop was engaged in providing Portuguese-language versions of works from across different literary genres, including popular picaresque novels, to the Lusophone community in Paris.

Even though the Portuguese translators responsible for producing the Portuguese-language versions of these anonymous novels did not work for Aillaud, the individual initiative to translate and publish such books appears to have been symptomatic of the recognition of the importance of publishing literary works in Portuguese to cater for the Portuguese exile community and even to gain access to the cultural enclave that Aillaud's bookshop ended up to become. In this context, the literary translations functioned complementarily with other activities aimed at preserving multilingualism, e.g. the setting up of a Lusophone school.

Preliminary data seem to suggest that the provision of translated novels functioned similarly in Rio de Janeiro. The collected data indicate that all literature published in Portuguese in Paris was soon after made available in the Portuguese Reading Cabinet in Rio de Janeiro and that this institution was also, on its own terms, a project of resistance to cultural assimilation. This research avenue should be pursued in future work on the profile of Portuguese migrants and, most notably, on the presence of Absolutist exiles in nineteenth-century Rio de Janeiro.

The contextual analysis of the literary corpus also provided data on the growing number of migrant communities in nineteenthcentury Paris and Rio de Janeiro, hence making it possible to argue that these two cities constituted nineteenth-century global cities. Since these literary works seemed to have circulated mainly in Paris and in Rio de Janeiro, it was hypothesised that the target 
texts would textually show a commitment to helping the Portuguese migrant in global cities. Therefore, an analysis of inter-historical textual elements was undertaken in a particular target text. Future research will hopefully provide the analysis of the remaining eleven popular anonymous novels.

The pilot study of Don Severino Magriço seems to support the hypothesis. In fact, the first message the Portuguese Don Quijote attempts to convey is that we should not be afraid of the unknown, that there are no ghosts or werewolves, only humans. Moreover, the likely reader of this target text was generally Portuguese and thus a descendant of the fearless navigators whose exploits are recalled in the novel's opening chapter.

Similar to the seventeenth-century and twenty-first-century literary works studied by Guillén and Domínguez, Don Severino Magriço is a picaresque adventurous novel with a Robinsonade structure, in which the protagonist encounters several characters of different national origins. However, and most importantly, nineteenth-century Literary History, strongly influenced by Herder's philosophy, draws attention to the comparison of literary canons. While in Cervantes' work the use of fictional texts as a means of apprehending the real world was considered a symptom of madness, in the nineteenth-century Portuguese version of the quixotic narrative, anthologies of foreign masterpieces are accepted as a suitable means of getting to know the character, the spirit and the behaviour of the different migrant communities in Paris and in Rio de Janeiro. The Portuguese Don Quijote seems to be advising all fellow Portuguese knights-errant in exile to trust in literature to lay bare the true essence of the global neighbour.

Finally this bit of quixotic madness should be permitted to anyone who undertook the moving crusade of helping mobile Portuguese exiles and migrants to re-discover a home for themselves in the hybrid cities of Paris and Rio. 


\section{References}

Abreu, Márcia et al. Caminhos do romance no Brasil: séculos XVIII e XIX. Caminhos do romance. Universidade Estadual de Campinas, 2005. Web. 6 June 2016. <http://www.caminhosdoromance.iel.unicamp.br/>

Aillaud, Jean-Pierre. Catalogo dos livros portuguezes e latinos publicados em Pariz por J.P. Aillaud e outros que se achão á venda em sua casa. Paris: Typographia de Fain e Thenot, 1844.

. Catalogo dos livros portuguezes e latinos publicados em Pariz por J.P. $\overline{\text { Aillaud }}$ e outros que se achão á venda em sua casa. Sèvres: Typographia de M. CERF, 1851.

. Catalogo dos livros portuguezes e latinos publicados em Pariz por J.P.

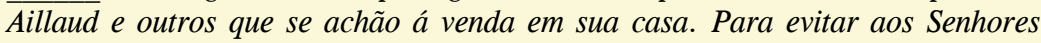
Livreiros... Sèvres: Typographia de M. CERF, 1851.

Azevedo, Fabiano Cataldo. Contributo para traçar o perfil do público leitor do Real Gabinete Português de Leitura: 1837-1847. Ci. Inf. Brasília 37.2 (2008): 20-31. Accessed 4 July 2016. <http://www.scielo.br/pdf/ci/v37n2/a02v37n2. pdf $>$

Boaventura, João. Do Real Colégio de Nobres na $7^{\mathrm{a}}$ colina de Lisboa e do colégio de Fontenay-aux-Roses a $7 \mathrm{kms}$ de Paris $-2^{\text {a }}$ parte. De Rerum Natura [Da natureza das coisas], 2012. Accessed 6 June 2016.

Catálogo dos livros da Bibliotheca Fluminense. Rio de Janeiro: Typographia Tenevet e Rua d'Ajuda 16, 1866. Biblioteca Nacional Digital do Brasil, accessed 4 July 2016. < http://bdlb.bn.br/acervo/handle/123456789/32412>

Catálogo dos livros do Gabinete Portuguez de Leitura no Rio de Janeiro. Rio de Janeiro: Typ. Commercial de F. de O. Q. Regadas, 1858.

Casanova, Pascale. The World Republic of Letters. Translated by M. B. DeBevoise. Cambridge, MA: Harvard University Press, 2004. 
Céspedes y Meneses, Gonzalo. Fortuna varia del Soldado Pindaro. In: Biblioteca de autores españoles desde la formación del lenguaje hasta nuestros días: novelistas posteriores a Cervantes (col. Don Cayetano Rosell). Tomo XVIII. Madrid: M. Rivadeneyra (1851): 273-375.

Cronin, Michael. Translation and Identity. London and New York: Routledge, 2006.

. The Expanding World: Towards a Politics of Microspection. Hants: Zero Books, 2012.

D. Severino Magriço ou o Dom Quichote portuguez. Paris: Pillet fils aîné, 1851.

Denis, Ferdinand. Journal : 1829-1848 (edition et notes de Pierre Moreau). Fribourg/Paris: Libraire de l'Université, 1932.

Domínguez Pietro, César. "Novela, cosmopolitismo e integración europea." Oihenart 1.25 (2010): 189-198. Accessed July 4th 2016 . < http://www. euskomedia.org/PDFAnlt/literatura/25/25189198.pdf >

Eça de Queirós. The City and the Mountains. Translated by Margaret Jull Costa. New York: New Directions Publishing Corporation, 2008.

Fonseca, José da. Prosas selectas ou escolha dos melhores logares antigos $e$ modernos. Paris: Livraria Europea de Baudry, 1837.

Garcia, Maria Madalena A. de Moura Machado and MARTINS, Lígia de Azevedo. Inventário do arquivo histórico da Bibloteca Nacional (1796-1950). Lisboa: Biblioteca Nacional, 1996.

Guillén, Claudio. "The Sun and the Self: notes on some responses to exile." Aesthetics and the Literature of Ideas: Essays in Honor of A. Owen Aldridge. Eds. JOST, François and FRIEDMAN, Melvin J. Newark: University of Delaware Press and London and Toronto: Associated University Presses (1990): 268-282. 1995. . El sol de los desterrados: literatura y exilio. Barcelona: Quaderns crema, 
Guimarães, Agostinho de Freitas. "Novo catálogo de escolhidos livros em portuguez." Folhinha de Utilidade Publica para o anno de 1849. Rio de Janeiro (1849): 3-72. Biblioteca Nacional Digital do Brasil, accessed 4 July 2016. < http://bdlb.bn.br/acervo/handle/123456789/48568>

Innocencio Francisco da Silva and ARANHA, Brito. "João da Cunha Neves e Carvalho Portugal.” Dicionário Bibliográfico Português. Lisboa: Imprensa Nacional 3.0 (1858-1923): 355-367.

Insee - Institut National de Statistiques et d'Etudes Economiques. Recensements de 1851 à 1921: Tableaux T02 et T29. Accessed 4 July 2016. < http://www. insee.fr/fr/service/bibliotheque/tableaux_sgf/tableaux.asp?domaine $=\mathrm{rec}>$

Laharie, Patrick, ed. Liste générale des brevetés de l'imprimerie et de la librairie. ler Empire et Restauration, 2003. Archives Nationales, accessed 4 July 2016. < http://www.archivesnationales.culture.gouv.fr/chan/chan/pdf/sm/ F18(I) $14-16,18,22,25 \% 20$ A-C.pdf $>$

Maia, Rita Bueno. De como o pícaro chegou a Portugal e aí se apresentou: contributo para a história da recepção do romance picaresco espanhol no sistema literário português. Diss. University of Lisbon, 2012.

Marcel, J.J. "Le sac d'Adb-êl-Qader, ou la destinée et Suite de l'Histoire d'Abdêl-Qader". Contes du Cheykh Êl-Modhdy, traduits de l'arabe après le manuscript original. Tome II. Paris : Imprimerie de Félix Locquin (1833): 218-230 \& 234274.

Oliveira, Paulo Motta. Viagens quase esquecidas. O imaginário das viagens: literatura, cinema e banda desenhada. ÁLVARES, Maria Cristina Daniel, CURADO, Ana Lúcia Amaral and SOUSA, Sérgio Paulo Guimarães de V.N. (org.). Famalicão: Edições Húmus and CEHUM, 2013. pp. 35-45. RepositóriUM, accessed 5 July 2016. < https://repositorium.sdum.uminho.pt/bitstream/.../ OImaginariodasViagens_DIGITAL.pdf >

Plancy, Colin de, and Simon, Jacques-Albin. "Roderik ou Rodrigue" Dictionnaire des sciences occultes... ou Répertoire universel des êtres, des personnages, des livres... qui tiennent aux apparitions, aux divinations à la magie.... Encyclopédie théologique. Ed. M. l'abbé Migne. Paris : Vol. 48-49. Ateliers catholiques du Petit-Montrouge. pp. 401-404. Gallica. Accessed 5 July 2016. < http://gallica. 
bnf.fr/ark:/12148/bpt6k2067490.r = Dictionnaire \%20des \%20sciences \% 20 occultes $>$

Protásio, Daniel Estudante. Pensamento histórico e acção política do $2^{\circ}$ Visconde de Santarém (1809-1855). Diss. University of Lisbon, 2008.

Pym, Anthony. Method in Translation History. Manchester: St. Jerome, 1998.

Quinhones, António Guedes de. Memórias de um Miguelista Renegado. A Guerra Civil e D. Miguel exilado (Pref. Leitura e Notas de Maria Teresa Mónica). Lisboa: Alfa, 1990.

Ramos, Vítor. A edição de língua portuguesa em França (1800-1850): repertório geral dos títulos publicados e ensaio crítico. Paris: Centro Cultural Português Fundação Calouste Gulbenkian, 1972.

Santos, Maria de Lourdes Costa Lima dos. Intelectuais portugueses na primeira metade de oitocentos. Lisboa: Editorial Presença, 1985.

Soriano, Luz. História da Guerra Civil e do estabelecimento do governo parlamentar em Portugal comprehendendo a História Diplomática e Política deste reino desde 1777 até 1834. Lisboa: Imprensa Nacional, 8.0 (1866-1890): 195198. Biblioteca Nacional Digital, accessed 4 July 2016. < http://purl.pt/12103>

Thomnson, Ronald B. The Concession of Évora Monte: the failure of liberalism in nineteenth-century Portugal. London: Lexington Books, 2014.

Van Der Veer, Peter. Cosmopolitan Options. Etnográfica. Lisboa 6.1 (2002): 15-26. Accessed 4 July 2016. < http://ceas.iscte.pt/etnografica/docs/vol_06/ N1/Vol_vi_N1_15-26.pdf >

Veiga, Claudio. Um brasileiro soldado de Napoleão. São Paulo: Editora Ática, 1979.

Ventura, António. As guerras liberais. Lisboa: QuidNovi, 2008. 
Viale, António José. Elogio Histórico do Senhor João da Cunha Neves e Carvalho Portugal, socio efectivo da Academia Real das Ciências de Lisboa, lido na sessão pública da mesma academia em 10 de março de 1861. Lisboa: Typographia da mesma academia, 1861.

Recebido em: 13/06/2016

Aceito em: 05/10/2016

Publicado em janeiro de 2017 